Vol.61: e18160758, 2018

http://dx.doi.org/10.1590/1678-4324-2018160758

ISSN 1678-4324 Online Edition
BRAZILIAN ARCHIVES OF

BIOLOGY AND TECHNOLOGY

AN INTERNATIONAL JOURNAL

\title{
Oxidative Damage and Antioxidant Response in Chenopodium murale L. Exposed to Elevated Levels of Zn
}

\author{
Parzhak Zoufan ${ }^{1 *}$, Amer Karimiafshar ${ }^{1}$, Sara Shokati ${ }^{1}$, Payman Hassibi ${ }^{2}$, Saadat \\ Rastegarzadeh $^{3}$ \\ ${ }^{1}$ Department of Biology, Faculty of Science, Shahid Chamran University of Ahvaz, Ahvaz, Iran. ${ }^{2}$ Department of \\ Agronomy and Plant Breeding, Faculty of Agriculture, Shahid Chamran University of Ahvaz, Ahvaz, Iran. \\ ${ }^{3}$ Department of Chemistry, Faculty of Science, Shahid Chamran University of Ahvaz, Ahvaz, Iran.
}

\begin{abstract}
Present study was carried out to investigate the effects of different $Z n$ concentrations on growth and some antioxidant responses in Chenopodium murale L. The seeds were sown on the pots. 45-day plants were transferred to hydroponic solution containing 0.2 (control), 150, 300 and $600 \mu \mathrm{M} \mathrm{Zn.} \mathrm{The} \mathrm{plants} \mathrm{were} \mathrm{harvested} \mathrm{at} 6$ days after applying Zn treatments and some parameters were evaluated including plant length, fresh weight, photosynthetic pigments, malondialdehyde (MDA), ascorbate, proline and enzymatic antioxidants such as catalase (CAT), guaiacol peroxidase (GPX) and superoxide dismutase (SOD). Zn concentration showed a considerable increase in the shoot and root as the concentration of Zn increased in the medium, meanwhile the roots were characterized by higher $Z n$ accumulation. At $150 \mu \mathrm{M} \mathrm{Zn}$, the length and fresh weight did not show important changes compared to the control, but these parameters decreased at 300 and $600 \mu \mathrm{M} Z \mathrm{Zn}$. With increasing Zn doses, the content of total chlorophyll declined, and also the content of carotenoids elevated. Excess $\mathrm{Zn}$ led to an increase in lipid peroxidation, free proline and ascorbate pool. Moreover, elevated Zn levels enhanced the activities of CAT, GPX and SOD. C. murale probably tolerates Zn concentrations up to $150 \mu M$ using the production of carotenoid, proline and ascorbate as well as enhanced activity of enzymatic antioxidants. Higher Zn treatments seem to be toxic due to a severe decline in growth.
\end{abstract}

Key words: Ascorbate, Enzymatic antioxidant, Lipid peroxidation, Proline, Zinc

\footnotetext{
*Author for correspondence: p.zoufan@scu.ac.ir or parzhakzoufan@yahoo.com
} 


\section{INTRODUCTION}

Zinc (Zn), as a micronutrient heavy metal, is required for normal growth and metabolism in plants. $\mathrm{Zn}$ is taken up by the roots mainly as $\mathrm{Zn}^{+2}$ free ions from soil solution ${ }^{1}$. Zn transporters primarily belong to ZIP (Zrt/IRT-like protein) family. Some of them are preferentially expressed and localized in the plasma membrane of root epidermal cells ${ }^{2}$. $\mathrm{Zn}$ is a structural component of the enzymes including carbonic anhydrase, alcohol dehydrogenase, superoxide dismutase (SOD) and RNA polymerase and it also serves as cofactor and activator in some enzyme reactions; it is involved in metabolism of lipids, carbohydrates and nucleic acids ${ }^{3}$. Moreover, integrity preservation of ribosomes and biomembranes is dependent on $\mathrm{Zn}$ existence in the plant ${ }^{1}$. $\mathrm{Zn}$ is also recognized to reduce oxidative stress induced by other metals ${ }^{4}$. Despite having a critical role in plant physiological processes, high concentrations of $\mathrm{Zn}$ are resulted in toxicity in plants. Toxicity symptoms and tolerance mechanisms to heavy metals vary among different plant species, even within the populations of the same species ${ }^{3}$. The most general symptoms of excess $\mathrm{Zn}$ are growth inhibition, biomass reduction, leaf chlorosis, senescence induction and photosynthesis damage. Furthermore, excess $\mathrm{Zn}$ can interfere with acquisition and transport of some nutrients ${ }^{5,6}$ and leads to $\mathrm{Mn}$ and Fe deficiency in plant shoots ${ }^{7}$.

In plants subjected to metal stress, an imbalance in producing and removing ROS induces oxidative stress through Haber-Weiss reaction ${ }^{3,8}$. ROS oxidize and destroy major biomolecules such as lipids, proteins, nucleic acids and pigments ${ }^{3}$. Nevertheless, the plants employ enzymatic antioxidants including superoxide dismutase (SOD; EC 1.15.1.1), catalase (CAT; EC 1.11.1.6) and peroxidase (POX; EC 1.11.1.7), together with non-enzymatic antioxidants such as ascorbate ${ }^{9,10}$ (AsA), proline ${ }^{8,11,12}$ to minimize harmful effects of oxidative stress and detoxify ROS caused by metal stress ${ }^{8}$. Some studies have been reported that excess $\mathrm{Zn}$ doses can induce oxidative stress, and also change antioxidant enzyme activities ${ }^{8,9,10,13}$. These results showed that $\mathrm{Zn}$ toxicity avoidance greatly depends on the activity of SOD,

CAT and guaiacol peroxidase (GPX). SOD, as first line of antioxidant defense against ROS, converts superoxide anion $\left(\mathrm{O}_{2}{ }^{\circ}\right)$ to hydrogen peroxide $\left(\mathrm{H}_{2} \mathrm{O}_{2}\right)$, which is then reduced to water and molecular oxygen by POX and CAT ${ }^{14}$. AsA, as a water-soluble antioxidant and redox buffer, can eliminate a variety of ROS; meanwhile contribute to reduce metal-induced oxidative stress as cofactor of ascorbate peroxidase ${ }^{15}$. Proline, as an organic osmolyte, is known to play principal role in osmoregulation and preventation of protein denaturation. A strong correlation between proline accumulation and antioxidant response has been reported under metal stress ${ }^{16}$.

Chenopodium murale L. (Amaranthaceae family) broadly grows in industrial area of steel production companies, located in southeast of Ahvaz city in Iran, where smelting activities lead to release metal particles such as $\mathrm{Zn}$ into the environment. There is no information about the effect of heavy metal stress on physiological and biochemical responses of the plants grown in this area. This study hence was conducted to investigate the effect of different concentrations of $\mathrm{Zn}$ under hydroponic system on growth parameters and some of antioxidant responses in $C$. murale collected from mentioned area. These results probably will be useful to evaluate $\mathrm{Zn}$ tolerance by this plant species. 


\section{MATERIAL AND METHODS}

\section{Plant culture and growth conditions}

Seeds of $C$. murale were collected from areas surrounding steel production industries located in southeast Ahvaz city, Khuzestan province of Iran where the activity of steel companies leads to release heavy metal particles into the environment. This area has been located in the geographical position of $31^{\circ} 20^{\prime} \mathrm{N}$ latitude and $48^{\circ} 40^{\prime} \mathrm{E}$ longitude. The seeds were sterilized with $20 \%$ $(\mathrm{v} / \mathrm{v})$ sodium hypochlorite and sown on the surface of commercial soil with NPK (12.4: 4.5: 14.7) fertilizer. Irrigation was performed with tap water three times per week. The 45-day-old plants were transferred to liquid cultures with 0.1 strength modified Johnson's nutrient solution ${ }^{17}$ containing micro and macro elements: $2.5 \mu \mathrm{M} \mathrm{H}_{3} \mathrm{BO}_{3}, 0.2 \mu \mathrm{M} \mathrm{MnSO}_{4} . \mathrm{H}_{2} \mathrm{O}, 0.2 \mu \mathrm{M}$ $\mathrm{ZnSO}_{4} 7 \mathrm{H}_{2} \mathrm{O}, 0.05 \mu \mathrm{M} \mathrm{CuSO}_{4} 5 \mathrm{H}_{2} \mathrm{O}, 0.05 \mu \mathrm{M} \mathrm{Na}_{2} \mathrm{MoO}_{4}, 2.0 \mu \mathrm{M}$ Fe-EDTA, $1000 \mu \mathrm{M} \mathrm{Ca}\left(\mathrm{NO}_{3}\right)_{2} 4 \mathrm{H}_{2} \mathrm{O}, 400 \mu \mathrm{M} \mathrm{CaSO}_{4} 2 \mathrm{H}_{2} \mathrm{O}, 200 \mu \mathrm{M} \mathrm{KH}_{2} \mathrm{PO}_{4}, 400 \mu \mathrm{M}$ $\mathrm{K}_{2} \mathrm{SO}_{4}$. The $\mathrm{pH}$ of the growth medium was adjusted to $6.0 \pm 0.3$. In order to supply enough oxygen, nutrient solutions were continuously aerated using air pumps. After 7 days growing in the mentioned solution, the plants were transferred to new complete nutrient solutions with different concentrations of $\mathrm{Zn}\left(\mathrm{NO}_{3}\right)_{2} 6 \mathrm{H}_{2} \mathrm{O}$ including 0.2 (control), 150, 300 and $600 \mu \mathrm{M}$ for 6 days. All the steps of experiment were carried out under controlled conditions with $16 \mathrm{~h} \mathrm{light} / 8 \mathrm{~h}$ dark, $25^{\circ} \mathrm{C} / 20^{\circ} \mathrm{C}$ day-night cycle. The plants were illuminated with $150 \mu \mathrm{mol}$ photons $\mathrm{m}^{-2} \mathrm{~s}^{-1}$ during light period. The nutrient solutions are renewed once every 3 days. The plants were harvested 6 days after $\mathrm{Zn}$ treatments. Shoot and root length and fresh weight were recorded during harvesting. Following exposure to different $\mathrm{Zn}$ treatments, all the experiments associated to hydroponic solution were repeated three times using $10 \mathrm{~L}$ containers. For each replication (including different $\mathrm{Zn}$ concentrations), the twelve containers (35 plants per container) were prepared and used to analyze various parameters at harvest time.

\section{Measurement of $\mathrm{Zn}$ concentration}

At harvest time, to eliminate $\mathrm{Zn}$ from the root surface, the roots were completely immersed in $0.1 \mathrm{M}$ EDTA- $\mathrm{Na}_{2}$ for $10 \mathrm{~min}$, and then washed three times with deionized water. After separating of roots and shoots, the plant samples were dried at $72{ }^{\circ} \mathrm{C}$ for $48 \mathrm{~h}$ in an oven. Dried powders $(1 \mathrm{~g})$ were digested with $10 \mathrm{ml}$ of $65 \% \mathrm{HNO}_{3}$ at room temperature for overnight. The digests were heated at $85{ }^{\circ} \mathrm{C}$ until the acid completely evaporated. Subsequently, the samples were mixed with $1 \mathrm{ml}$ of $30 \% \mathrm{H}_{2} \mathrm{O}_{2}$. After filtering, the solutions were made up to a volume of $50 \mathrm{ml}$ with deionized water ${ }^{18}$. The concentration of $\mathrm{Zn}$ was determined by a Flame Atomic Absorption Spectrometer instrument (GBC, Avanta model, Australia). Translocation factor (TF) and Bioconcentration factor (BF) were calculated as described by Rosén et al. ${ }^{19}$ :

Eq. (1) $\mathrm{TF}=\mathrm{Zn}$ concentration of the shoot $\left(\mathrm{mg} \mathrm{g}^{-1} \mathrm{DW}\right) / \mathrm{Zn}$ concentration of the root $\left(\mathrm{mg} \mathrm{g}^{-1} \mathrm{DW}\right)$

Eq. (2) $\mathrm{BF}=\mathrm{Zn}$ concentration of the shoot or root $\left(\mathrm{mg} \mathrm{g}^{-1} \mathrm{DW}\right) / \mathrm{Zn}$ concentration of the solution $\left(\mathrm{mg} \mathrm{L}^{-1}\right)$

\section{Measurement of pigment content}

The content of photosynthetic pigments was assayed consistent with Lichtenthaler ${ }^{20}$. The $0.5 \mathrm{~g}$ fresh weight of leaves was homogenized in $20 \mathrm{ml}$ of $80 \%$ (v/v) acetone, and then filtered. All steps were done under ice-cold conditions and weak light. The absorbance of the samples was measured at 470, 663.2 and $646.8 \mathrm{~nm}$ using an UV-Vis spectrophotometer (Optision 
2120UV PLUS, Korea). Total chlorophyll and carotenoid amounts were reported as $\mathrm{mg} \mathrm{g}^{-1} \mathrm{FW}$.

\section{Assessment of lipid peroxidation, ascorbic acid and proline}

Lipid peroxidation was reported as malondialdehyde (MDA) amount in accordance with Heath and Packer ${ }^{21}$. Fresh weight of leaves $(0.5 \mathrm{~g})$ was homogenized in $5 \mathrm{ml}$ of $0.1 \%(\mathrm{w} / \mathrm{v})$ trichloroacetic acid (TCA), and then centrifuged at $10000 \times \mathrm{g}$ for $10 \mathrm{~min}$. Four $\mathrm{ml}$ of $20 \%$ TCA solution containing $0.5 \%(\mathrm{w} / \mathrm{v})$ thiobarbituric acid (TBA) was added to $1 \mathrm{ml}$ of supernatant and incubated at $95{ }^{\circ} \mathrm{C}$. After $30 \mathrm{~min}$, the mixture was immediately transferred to an ice bath, and again centrifuged at $10000 \times \mathrm{g}$ for 10 min. The absorbance of supernatant was determined spectrophotometrically at 532 and $600 \mathrm{~nm}$. MDA concentration was represented in $\mu \mathrm{mol} \mathrm{g}{ }^{-1} \mathrm{FW}$ using the extinction coefficient equal to 155 $\mathrm{mM}^{-1} \mathrm{~cm}^{-1}$.

Ascorbate measurement was performed following a modification of the method of Mukherjee and Choudhuri ${ }^{22}$ and expressed as $\mu \mathrm{g} \mathrm{g}^{-1} \mathrm{FW}$. Using $10 \mathrm{ml}$ of $5 \%(\mathrm{w} / \mathrm{v})$ metaphosphoric acid, $0.5 \mathrm{~g}$ of fresh leaf was extracted. The homogenate was centrifuged at $10000 \times \mathrm{g}$ for $15 \mathrm{~min}$ at $4{ }^{\circ} \mathrm{C}$. The supernatant was used to assay total (AsA + DHA) and oxidized ascorbate (dehydroascorbate; DHA) contents. To determine total ascorbate amount, 0.5 $\mathrm{ml}$ of $3 \mathrm{mM}$ 2,6-dichloroindophenol sodium was added to $1 \mathrm{ml}$ of the supernatant to oxidize ascorbic acid to DHA. To assay DHA, $1 \mathrm{ml}$ of prepared supernatant was mixed with $0.5 \mathrm{ml}$ of deionized water. With addition of $1 \%(\mathrm{w} / \mathrm{v})$ thiourea solution, all the tubes were left without shaking for $20 \mathrm{~min}$. All the sample solutions were combined with $1 \mathrm{ml}$ of 10 $\mathrm{mM}$ 2,4-dinitrophenylhydrazine and then placed in the water bath at $50{ }^{\circ} \mathrm{C}$ for $1 \mathrm{~h}$. The reaction was stopped by transferring the tubes to an ice bath for $30 \mathrm{~min}$ and subsequently, $2.5 \mathrm{ml}$ of $85 \%$ (v/v) $\mathrm{H}_{2} \mathrm{SO}_{4}$ was gradually added to the samples under ice-cold conditions. After adding $1 \mathrm{ml}$ of $20 \%(\mathrm{v} / \mathrm{v})$ $\mathrm{H}_{2} \mathrm{SO}_{4}$, the amount of AsA + DHA and DHA was assayed at $520 \mathrm{~nm}$ using an UV-Vis spectrophotometer. Content of reduced ascorbate (AsA) was calculated by subtracting values of total ascorbate and DHA. L-ascorbic acid was used to prepare standard solutions.

Free proline assessment was done using a method described previously ${ }^{23}$. A $0.5 \mathrm{~g}$ of fresh weight was homogenized with $10 \mathrm{ml}$ of $3 \%(\mathrm{w} / \mathrm{v})$ sulfosalisylic acid under cold conditions. Following centrifugation $(10000 \times \mathrm{g}$ for $10 \mathrm{~min}$ at $4{ }^{\circ} \mathrm{C}$ ), the supernatant was exposed to $2 \mathrm{ml}$ of ninhydrin reagent and $2 \mathrm{ml}$ of glacial acetic acid. All the samples were incubated in a water bath at $100{ }^{\circ} \mathrm{C}$ for $1 \mathrm{~h}$ and immediately put on the ice bath to stop reaction. The samples were mixed with $4 \mathrm{ml}$ of toluene, then vortexed for $30 \mathrm{sec}$. After separation of two phases, the absorbance of supernatant containing toluene and proline was measured spectrophotometerically at $520 \mathrm{~nm}$. Proline amount was expressed as $\mu \mathrm{mol} \mathrm{\textrm {g } ^ { - 1 }}$ FW with regard to standard solutions of proline.

\section{Assessment of enzyme activity}

A $0.2 \mathrm{~g}$ of leave fresh weight was homogenized with $5 \mathrm{ml}$ of $100 \mathrm{mM}$ potassium phosphate buffer (PSB, pH 7.0) containing $0.1 \mathrm{mM}$ EDTA and 1 $\%$ (w/v) polyvinylpyrrolidone under ice-cold conditions according to Qiu et al. ${ }^{24}$. Homogenate was centrifuged at $15000 \times \mathrm{g}$ for $15 \mathrm{~min}$ at $4{ }^{\circ} \mathrm{C}$. The amount of soluble proteins in the supernatant was quantified as described by Bradford ${ }^{25}$. The supernatant was used to assay CAT, GPX and SOD activity in unit (U) $\mathrm{mg}^{-1}$ protein. Method of Aebi ${ }^{26}$ was used to determine spectrophotometerically CAT activity. Reaction mixture was contained 520 
$\mu 1$ of $50 \mathrm{mM}$ PSB (pH 7.8), $250 \mu 1$ of deionized water, $150 \mu 1$ of $100 \mathrm{mM}$ $\mathrm{H}_{2} \mathrm{O}_{2}$ and $80 \mu \mathrm{l}$ of protein extract. The reaction was started with addition of $\mathrm{H}_{2} \mathrm{O}_{2}$ to the reaction mixture and the decrease in absorbance was monitored by the consumption of $\mathrm{H}_{2} \mathrm{O}_{2}$ at $240 \mathrm{~nm}$ within $2 \mathrm{~min}$. One unit of CAT activity was defined as an absorbance decrease of $0.01 \mathrm{U} \mathrm{min}^{-1}$. GPX activity was assayed according to Hemeda and Klein ${ }^{27}$. The reaction mixture was prepared as $1430 \mu \mathrm{l}$ of $50 \mathrm{mM}$ PSB (pH 6.0), $500 \mu \mathrm{l}$ of $2 \%$ (v/v) $\mathrm{H}_{2} \mathrm{O}_{2}, 500$ $\mu \mathrm{l}$ of $50 \mathrm{mM}$ guaiacol and $70 \mu \mathrm{l}$ of protein extract. Following the addition of guaiacol, the increase of absorbance in the mixture was assayed by guaiacol oxidation and tetraguaiacol formation at $470 \mathrm{~nm}$ for $2 \mathrm{~min}$. An absorbance increase of $0.1 \mathrm{U} \mathrm{min}{ }^{-1}$ was reported as one unit of GPX activity. The activity of SOD was determined spectrophotometerically as described by Beauchamp and Fridovich ${ }^{28}$. Regarding inhibition of nitrobluetetrazolium (NBT) photochemical reduction by SOD, one unit of enzyme was defined as an amount of protein required to result in $50 \%$ inhibition of NBT reduction rate under irradiation. The reaction mixture was included $1450 \mu \mathrm{l}$ of $50 \mathrm{mM}$ PSB (pH 7.8), $300 \mu \mathrm{l}$ of $130 \mathrm{mM}$ methionine, $300 \mu \mathrm{l}$ of $750 \mu \mathrm{M}$ NBT, 300 $\mu \mathrm{l}$ of $0.1 \mathrm{mM}$ EDTA-Na $2,250 \mu \mathrm{l}$ of deionized water, $300 \mu \mathrm{l}$ of $20 \mu \mathrm{M}$ riboflavin and $100 \mu \mathrm{l}$ of enzyme extract. The tubes containing the reaction mixture were placed below a light source. After $15 \mathrm{~min}$, the absorbance of mixture was recorded at $560 \mathrm{~nm}$ using a dark control.

\section{Statistical analysis}

All the experiments were performed three replicates for each treatment as completely randomized designs. The data were analyzed using one-way analysis of variance (ANOVA). The means obtained from four $\mathrm{Zn}$ treatments were compared with each other by Duncan's Multiple Range Test at $p<0.05$ confidence level. Statistical analysis was carried out by the SPSS 16.0 package.

\section{RESULTS}

\section{Uptake of $\mathrm{Zn}$ and effect on growth characteristics and photosynthetic pigments}

According to Table 1, when the plants were supplemented with various $\mathrm{Zn}$ treatments, the $\mathrm{Zn}$ concentration in the shoots and roots showed a significant increase $(p<0.05)$ compared to control group $(0.2 \mu \mathrm{M} \mathrm{Zn})$. The highest $\mathrm{Zn}$ concentration was measured in shoots and roots grown at $600 \mu \mathrm{M} \mathrm{Zn}$ as 0.43 and $1.66 \mathrm{mg} \mathrm{g}^{-1} \mathrm{DW}$, respectively. Taking into account the values of TF, it was detected that shoot to root $\mathrm{Zn}$ concentration ratio was less than 1 . Table 1 illustrates that the values of BF were calculated less than one in both the shoots and roots. However, the roots mainly showed higher values in BF as compared to the shoots. The length of shoot and root exhibited a significant reduction $(p<0.05)$ compared to the control at 300 and $600 \mu \mathrm{M} \mathrm{Zn}$, but the plants treated with $150 \mu \mathrm{M} \mathrm{Zn}$ did not present considerable different for this parameter (Table 2). There was no meaningful difference between plants grown at 0.2 and $150 \mu \mathrm{M} \mathrm{Zn}$ in shoot and root fresh weight (Table 2). A significant decrease $(p<0.05)$ was found in total chlorophyll content of the plants grown in different $\mathrm{Zn}$ concentrations compared to the control and this reduction was proportional to the increase in the concentration of $\mathrm{Zn}$ (Fig. 1A). At concentrations of 300 and $600 \mathrm{Zn} \mu \mathrm{M}$, chlorophyll contents showed a remarkable decline compared with the control. $\mathrm{Zn}$ treatments resulted in an important increase $(p<0.05)$ in carotenoids content as compared to the control group (Fig. 1B). 
Table 1- Effect of various $\mathrm{Zn}$ treatments (control, 150, 300 and $600 \mu \mathrm{M}$ ) on shoot and root $\mathrm{Zn}$ concentration, $\mathrm{TF}$ and $\mathrm{BF}$.

\begin{tabular}{|c|c|c|c|c|c|c|}
\hline \multirow{2}{*}{ Harvest time } & \multirow{2}{*}{ Zn treatment $(\mu \mathrm{M})$} & \multicolumn{2}{|c|}{$\begin{array}{l}\text { Zn concentration }(\mathrm{mg} \\
\left.\mathrm{g}^{-1} \mathrm{DW}\right)\end{array}$} & \multirow[t]{2}{*}{$\mathrm{TF}$} & \multicolumn{2}{|c|}{$\mathrm{BF}$} \\
\hline & & Shoot & Root & & Shoot & Root \\
\hline before treatment & - & $\begin{array}{c}0.17 \\
\pm 0.01^{\mathrm{d}}\end{array}$ & $\begin{array}{c}0.21 \\
\pm 0.02^{\mathrm{d}}\end{array}$ & $\begin{array}{c}0.87 \\
\pm 0.11^{\mathrm{a}}\end{array}$ & $\begin{array}{c}0.10 \\
\pm 0.003^{\mathrm{a}}\end{array}$ & $\begin{array}{c}0.12 \pm \\
0.2^{\mathrm{d}}\end{array}$ \\
\hline \multirow{4}{*}{$\begin{array}{c}6 \text { days after } \\
\text { Treatment }\end{array}$} & (control) 0.2 & $\begin{array}{l}0.18 \pm \\
0.007^{\mathrm{d}}\end{array}$ & $\begin{array}{l}0.22 \pm \\
0.02^{\mathrm{d}}\end{array}$ & $\begin{array}{l}0.82 \pm \\
0.06^{\mathrm{a}}\end{array}$ & $\begin{array}{l}0.11 \pm \\
0.003^{\mathrm{a}}\end{array}$ & $\begin{array}{l}0.13 \pm \\
0.01^{\mathrm{d}}\end{array}$ \\
\hline & 150 & $\begin{array}{l}0.33 \pm \\
0.008^{c}\end{array}$ & $\begin{array}{l}1.53 \pm \\
0.01^{\mathrm{c}}\end{array}$ & $\begin{array}{l}0.22 \pm \\
0.008^{\mathrm{d}}\end{array}$ & $\begin{array}{l}0.10 \pm \\
0.007^{\mathrm{a}}\end{array}$ & $\begin{array}{l}0.46 \pm \\
0.05^{\mathrm{a}} \\
\end{array}$ \\
\hline & 300 & $\begin{array}{l}0.38 \pm \\
0.02^{\mathrm{b}}\end{array}$ & $\begin{array}{l}1.58 \pm \\
0.01^{\mathrm{b}}\end{array}$ & $\begin{array}{l}0.24 \pm \\
0.01^{\mathrm{c}}\end{array}$ & $\begin{array}{l}0.06 \pm \\
0.004^{\mathrm{b}}\end{array}$ & $\begin{array}{l}0.27 \pm \\
0.002^{\mathrm{b}}\end{array}$ \\
\hline & 600 & $\begin{array}{c}0.43 \pm \\
0.01^{\mathrm{a}}\end{array}$ & $\begin{array}{l}1.66 \pm \\
0.04^{\mathrm{a}}\end{array}$ & $\begin{array}{l}0.26 \pm \\
0.001^{\mathrm{b}}\end{array}$ & $\begin{array}{l}0.06 \pm \\
0.001^{\mathrm{b}}\end{array}$ & $\begin{array}{l}0.24 \pm \\
0.006^{\mathrm{c}}\end{array}$ \\
\hline
\end{tabular}

Values are expressed as mean $\pm \mathrm{SE}, N=3$ for each treatment, means in each column fallowed by different letters are significantly different at $P<0.05$.

Table 2- Effect of various $\mathrm{Zn}$ treatments (control, 150, 300 and $600 \mu \mathrm{M}$ ) on shoot and root length and fresh weight

\begin{tabular}{cccccc}
\hline \multirow{2}{*}{ Harvest time } & \multirow{2}{*}{$\begin{array}{c}\text { Zn treatment } \\
\end{array}$} & $(\mu \mathrm{M})$ & \multicolumn{2}{c}{ Length $(\mathrm{cm})$} & \multicolumn{2}{c}{ Fresh weight $(\mathrm{g}$ per plant) } \\
\cline { 2 - 5 } & - & $4.5 \pm 0.1^{\mathrm{a}}$ & $10.4 \pm 0.5^{\mathrm{a}}$ & $6.0 \pm 0.02^{\mathrm{a}}$ & $0.16 \pm 0.003^{\mathrm{a}}$ \\
\hline before treatment & $($ control) 0.2 & $7.3 \pm 0.1^{\mathrm{a}}$ & $19.4 \pm 0.5^{\mathrm{a}}$ & $7.6 \pm 0.1^{\mathrm{a}}$ & $0.32 \pm 0.02^{\mathrm{a}}$ \\
\hline \multirow{3}{*}{ 6 days after } & 150 & $6.8 \pm 0.3^{\mathrm{a}}$ & $18.5 \pm 0.7^{\mathrm{a}}$ & $7.2 \pm 0.3^{\mathrm{a}}$ & $0.31 \pm 0.01^{\mathrm{a}}$ \\
\cline { 2 - 5 } Treatment & 300 & $5.6 \pm 0.2^{\mathrm{b}}$ & $14.6 \pm 0.2^{\mathrm{b}}$ & $4.0 \pm 0.1^{\mathrm{b}}$ & $0.15^{\mathrm{b}}$ \\
\cline { 2 - 5 } & 600 & $4.3 \pm 0.3^{\mathrm{c}}$ & $14.3 \pm 0.2^{\mathrm{b}}$ & $3.2 \pm 0.1^{\mathrm{c}}$ & $0.12^{\mathrm{c}}$ \\
\cline { 2 - 5 }
\end{tabular}

Values are expressed as mean $\pm \mathrm{SE}, N=3$ for each treatment, means in each column fallowed by different letters are significantly different at $P<0.05$.

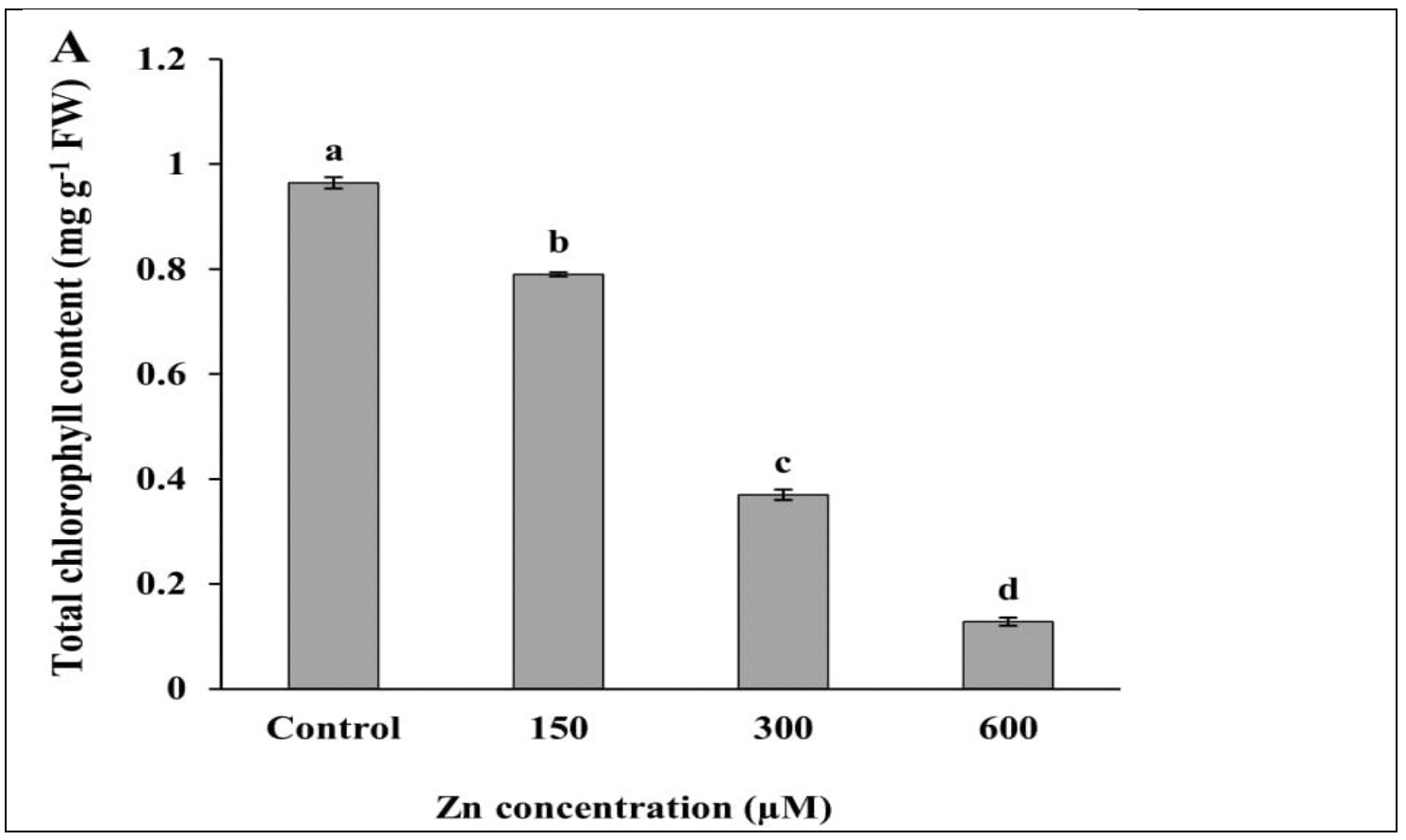




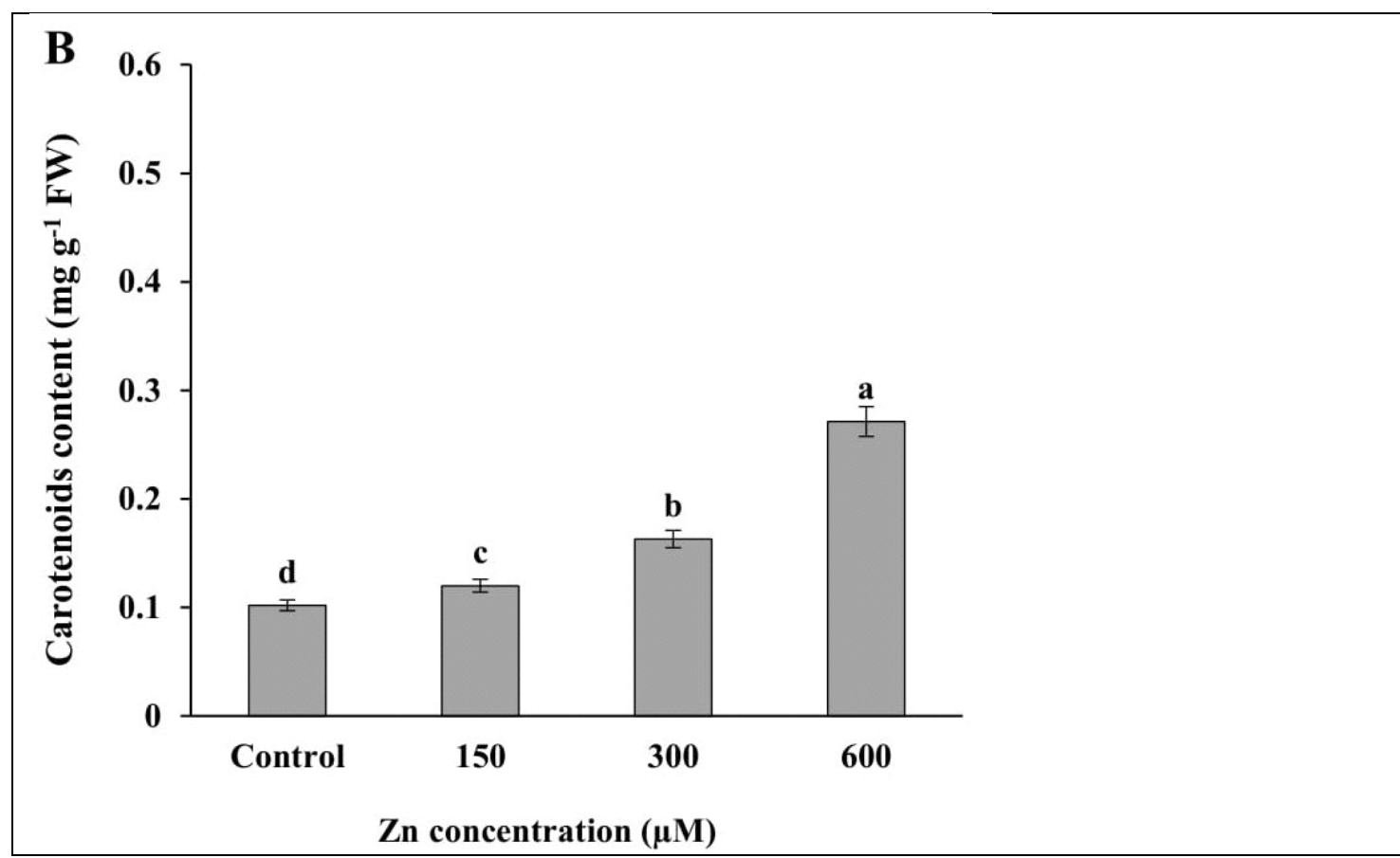

Figure 1- Effect of various $\mathrm{Zn}$ treatments (control, 150, 300 and $600 \mu \mathrm{M}$ ) on contents of total chlorophyll (A) and carotenoid (B) after 6 days of exposure to $\mathrm{Zn}$ treatments. Values are mean \pm SE for each treatment, $N=3$. Different letters indicate significantly different values at $P<0.05$ confidence level.

\section{Effect of $\mathrm{Zn}$ on lipid peroxidation, proline and ascorbate}

Increasing $\mathrm{Zn}$ supply levels were significantly effective $(p<0.05)$ on MDA content, and maximum MDA was assayed in plants treated with $600 \mu \mathrm{M} \mathrm{Zn}$ (Fig. 2A). The results indicated a significant increase $(p<0.05)$ in proline content in response to treatment of $\mathrm{Zn}$ (Fig. 2B). The highest accumulation of proline was measured in plants grown in the culture containing $600 \mu \mathrm{M}$ $\mathrm{Zn}$. Comparing to the control group, a considerable increase $(p<0.05)$ was observed in DHA + AsA, DHA and reduced AsA for the plants which were exposed to different treatments of Zn after 6-day period (Figs. $2 \mathrm{C}, \mathrm{D}, \mathrm{E}$ ). The ascorbate pool exhibited the greatest content in the plants supplied with $600 \mu \mathrm{M} \mathrm{Zn}$.

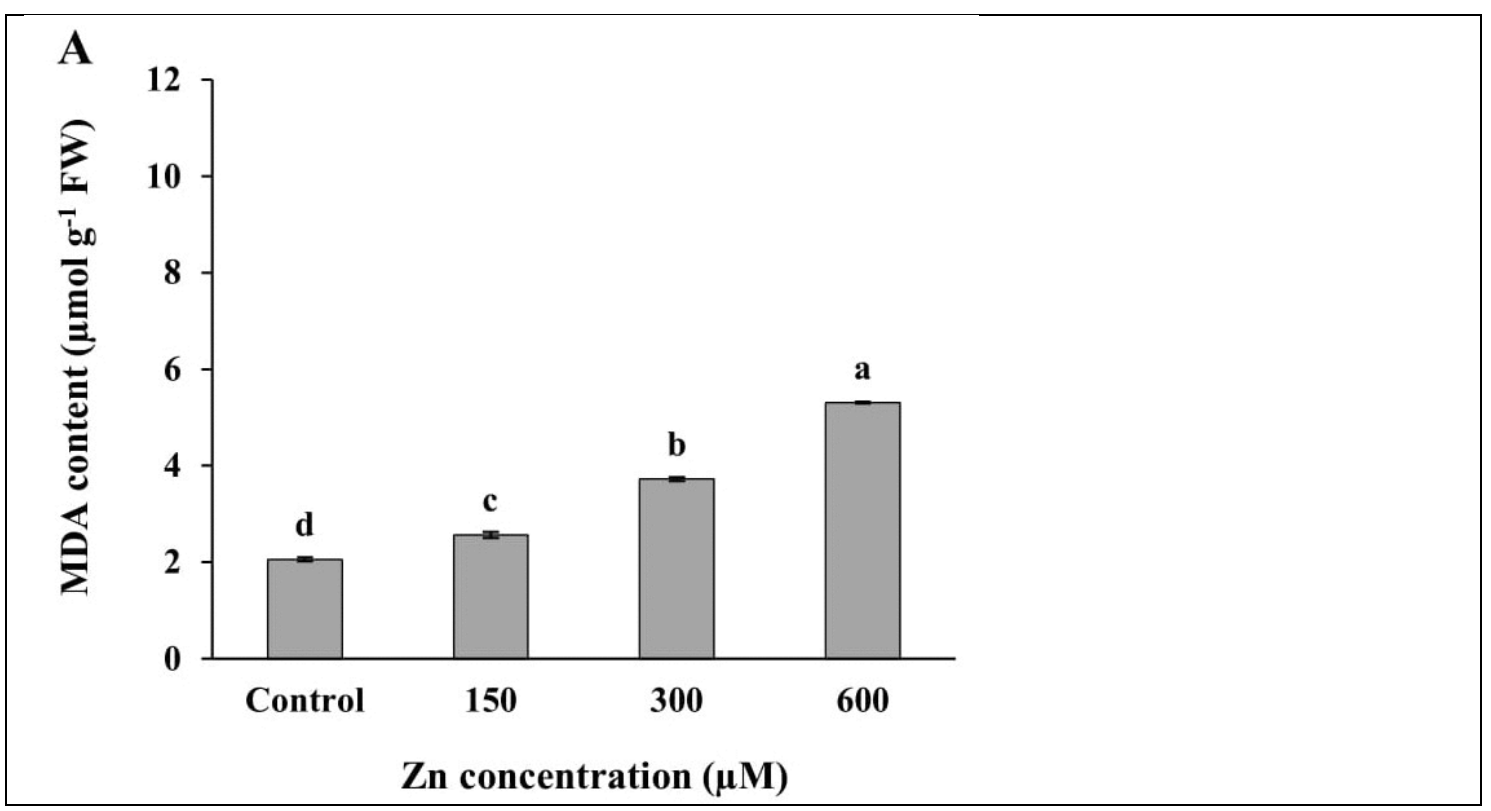




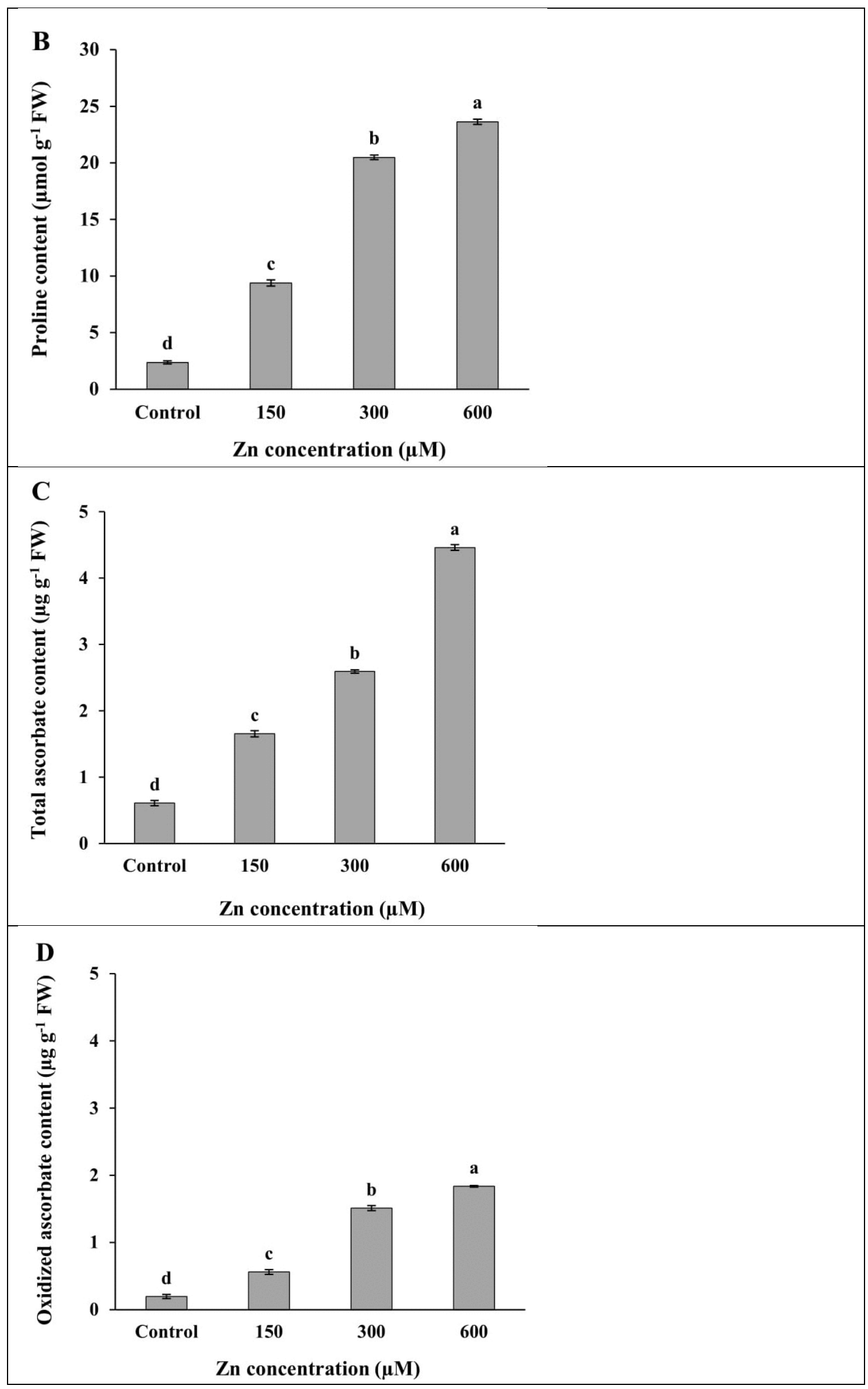

Braz. Arch. Biol. Technol. v.61: e18160758 2018 


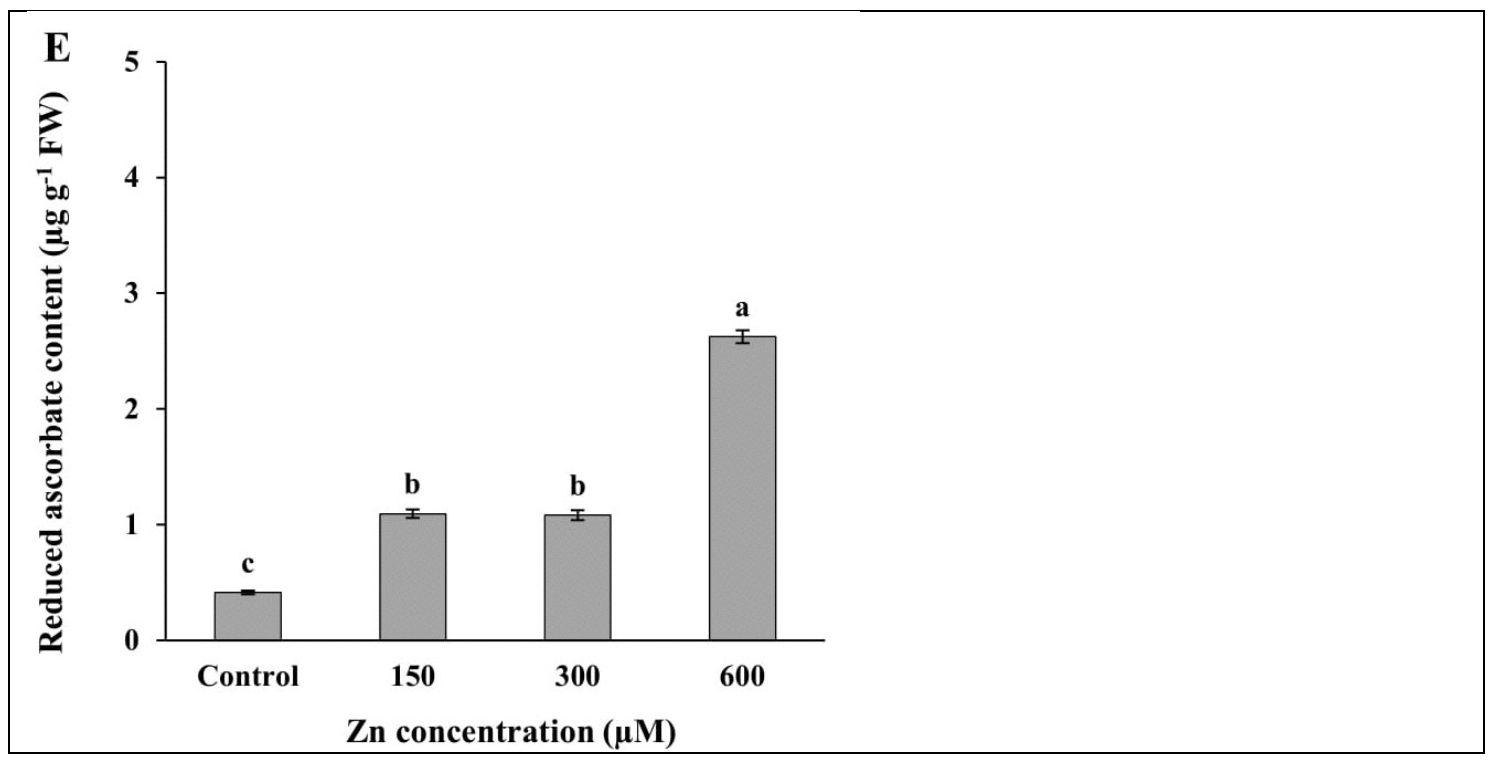

Figure 2- Effect of various $\mathrm{Zn}$ treatments (control, 150, 300 and $600 \mu \mathrm{M}$ ) on contents of MDA (A), proline (B), total ascorbate (C), oxidized ascorbate (D) and reduced ascorbate (E) after 6 days of exposure to $\mathrm{Zn}$ treatments. Values are mean $\pm \mathrm{SE}$ for each treatment, $N=3$. Different letters indicate significantly different values at $P<0.05$ confidence level.

\section{Effect of $\mathrm{Zn}$ activity of antioxidative enzymes}

The effect of various concentrations of $\mathrm{Zn}$ on enzyme activity is presented in Figure 3. A significant increase $(p<0.05)$ depended on $\mathrm{Zn}$ concentration in activity of enzymatic antioxidants including CAT, GPX and SOD was observed comparing to the control group during the experiment period. As shown in Figure $3 \mathrm{~A}$, the CAT activity did not show critical differences among the plants treated with 150,300 and $600 \mu \mathrm{M} \mathrm{Zn}$, but it increased in comparison with the control. There were significant differences $(p<0.05)$ among the plants grown at $\mathrm{Zn}$ concentrations higher than the control concentration in both GPX and SOD activities (Figs. 3 B, C).

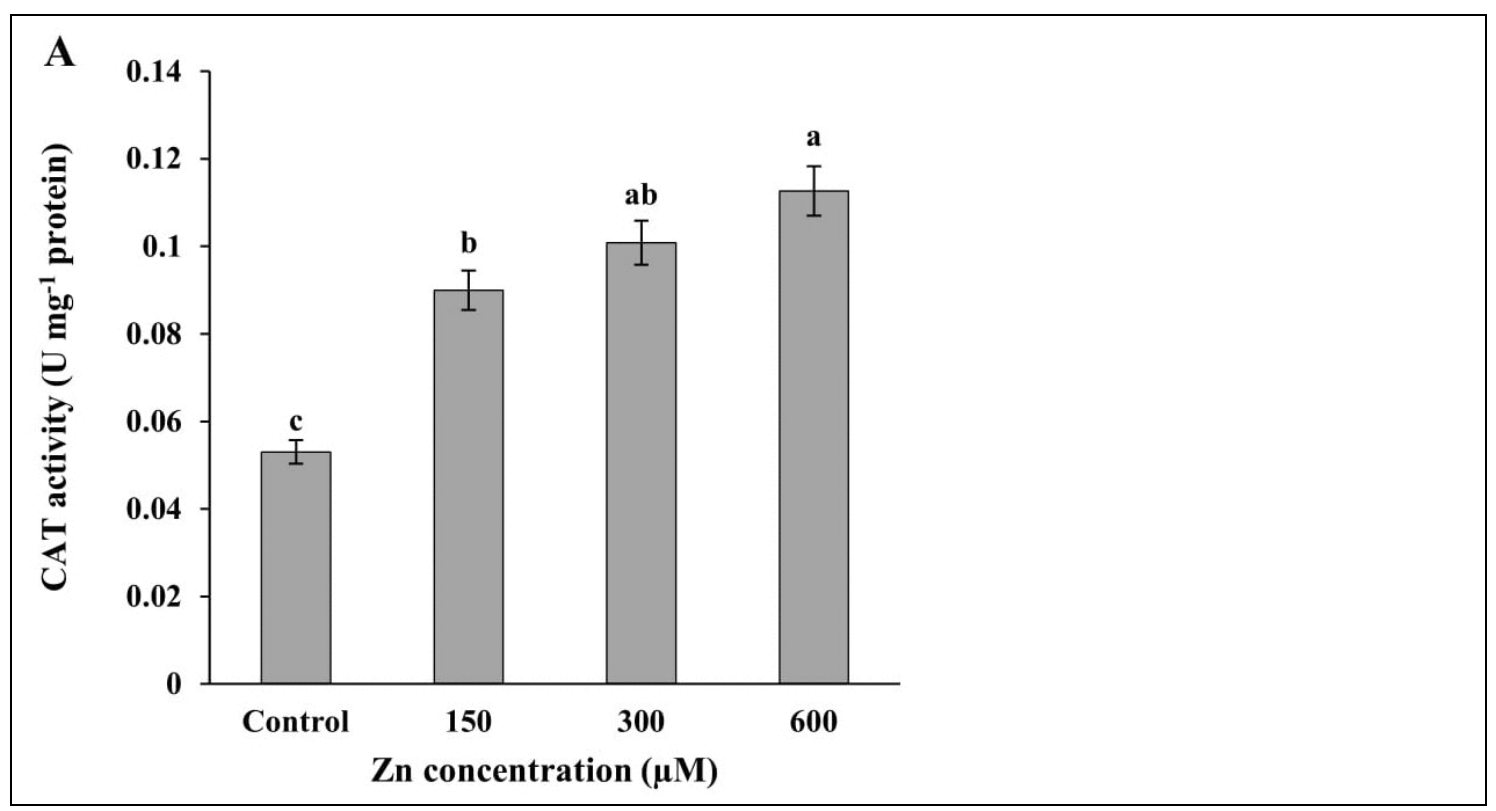




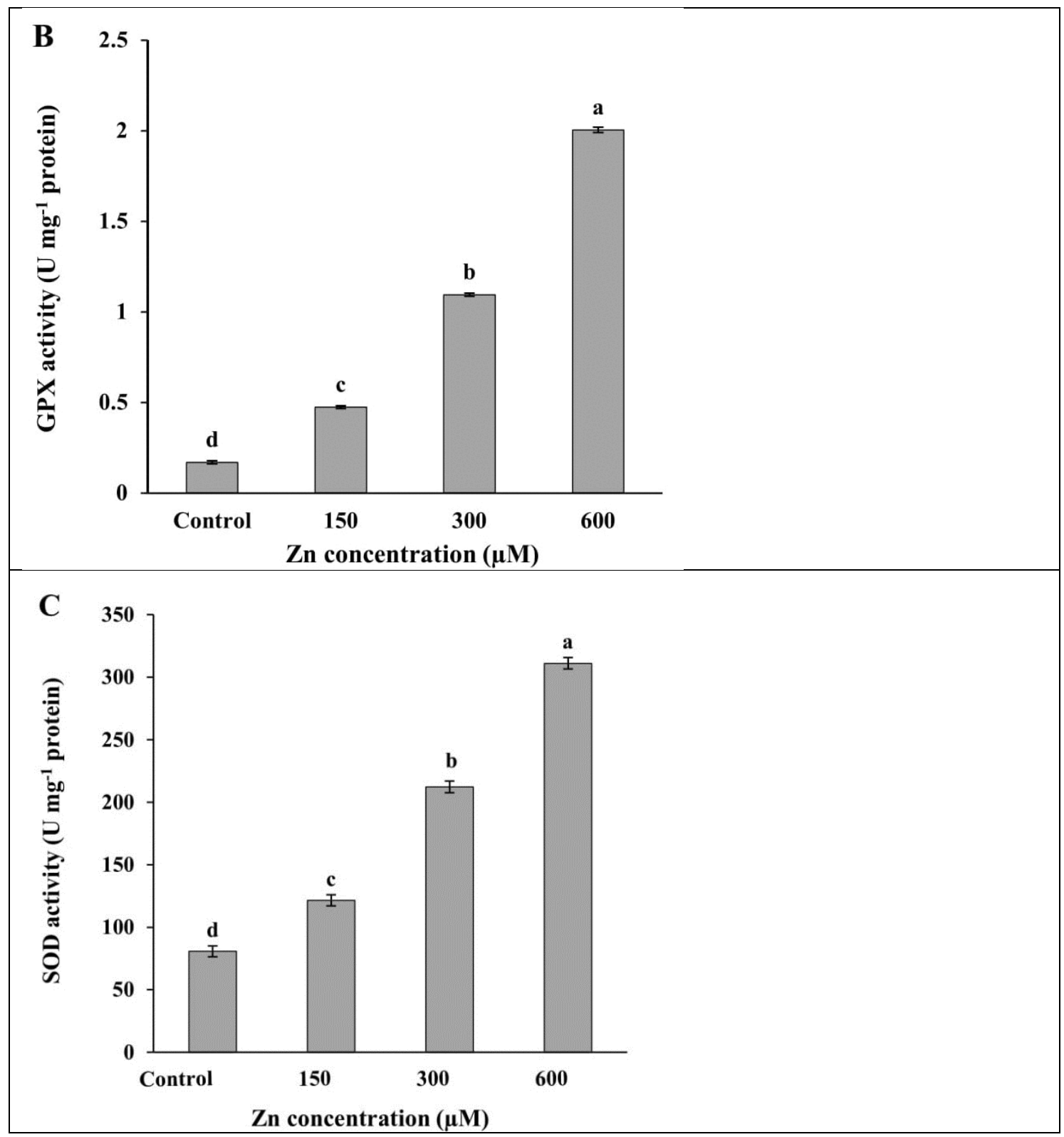

Figure 3-. Effect of various Zn treatments (control, 150, 300 and $600 \mu \mathrm{M}$ ) on activity of CAT (A), GPX (B) and SOD (C) after 6 days of exposure to Zn treatments. Values are mean \pm SE for each treatment, $N=$ 3. Different letters indicate significantly different values at $P<0.05$ confidence level.

\section{DISCUSSION}

In this study, $\mathrm{Zn}$ uptake by both shoots and roots showed an increase with increasing $\mathrm{Zn}$ concentrations in the growth medium. However, given organ $\mathrm{Zn}$ concentrations, and also TF and BF amounts, the roots exhibited the ability of higher $\mathrm{Zn}$ accumulation when compared with the aerial parts (Table 1). It has been pointed out that higher metal accumulation in roots is used as a tolerance strategy to prevent translocation of excess metal levels to photosynthetic organs and protect them against toxicity induced by metal accumulation ${ }^{29}$. A raise in root $\mathrm{BF}$ (compared to shoot $\mathrm{BF}$ ) with increasing $\mathrm{Zn}$ concentration in the solution, indicates that most $\mathrm{Zn}$ absorbed by $C$. murale is concentrated in the roots and a small fraction transported to the shoots to diminish $\mathrm{Zn}$ stress.

Toxicity caused by the concentrations higher than $150 \mu \mathrm{M} Z \mathrm{Zn}$ significantly reduced growth of the plants (Table 2). The growth and biomass 
maintenance is one of the most important properties in the plants to tolerate metal stress ${ }^{10}$. Some plants grown under $\mathrm{Zn}$ stress represented a strong decrease in organ elongation and biomass production ${ }^{7,9,5,30,31}$. Toxic $\mathrm{Zn}$ doses are known to exert the negative effects on the growth of plant by way of injury in nutrient elements availability ${ }^{30,31}$, disturbance in water balance and creating oxidative stress ${ }^{10}$; moreover, excess $\mathrm{Zn}$ prevents metabolic processes related to plant growth ${ }^{32}$. In this study, with increasing in $\mathrm{Zn}$ accumulation, the growth of shoots and roots presented a remarkable decline. Therefore, these results indicate that higher uptake can reduce the growth of $C$. murale through $\mathrm{Zn}$-induced toxicity, and also lipid peroxidation enhancement (Fig. 2A) and oxidative damage initiated by these doses may be some important reasons to decline growth and biomass production of $C$. murale.

In the present study, higher $\mathrm{Zn}$ concentrations considerably reduced total chlorophyll content. Nevertheless, the content of carotenoids showed an improving trend (Fig. 1). The decline in chlorophyll contents has been reported as one of the most general symptoms in some plant species exposed with toxic $\mathrm{Zn}$ levels $4,8,9,30,33$. Decrease in chlorophyll contents of the plants exposed to excess $\mathrm{Zn}$ concentrations may be due to either the decrease in chlorophyll synthesis or increase in its decomposition ${ }^{34}$. Li et al. ${ }^{8}$ have suggested that higher Zn doses probably destroy chloroplast membranes and induce chlorophyll hydrolysis. Chloroplast is one of important organelles to create ROS such as $\mathrm{O}^{-}{ }_{2}, \mathrm{H}_{2} \mathrm{O}_{2}$ and ${ }^{\circ} \mathrm{OH}$ (hydroxyl radicals). Elevated $\mathrm{Zn}$ can inhibit function of photosynthetic electron transport chain and thus induce ROS generation and oxidative stress ${ }^{35}$. Consequently, enhanced lipid peroxidation under higher $\mathrm{Zn}$ levels, can support the theory of chloroplast destruction and lead to a decline in chlorophyll content in $C$. murale. In Myracrodruon urundeuva under toxic $\mathrm{Zn}$ doses, enhanced carotenoids content has been attributed to their protective role for photosynthetic apparatus against ROS accumulation and oxidative stress ${ }^{10}$. ROS created by various stresses is suggested to support carotenoid biosynthesis by activating enzymes and genes involved in carotenogenesis ${ }^{36}$. Carotenoids display a pivotal role to scavenge ${ }^{1} \mathrm{O}_{2}$ (singlet oxygen) produced by other ROS types ${ }^{37}$. Hence, our study proposes that carotenoids accumulation is associated to their key function in protecting the plant cells against $\mathrm{Zn}$ - induced oxidative stress.

Following exposure to different $\mathrm{Zn}$ treatments, levels of MDA, free proline and ascorbate pool showed an increased trend with increasing $\mathrm{Zn}$ concentrations (Fig. 2) . It has previously been reported that toxic levels of $\mathrm{Zn}$ stimulate ROS production and lipid peroxidation (for example ${ }^{10,12,15}$ ). Oxidative stress mediated by non-redox metals such as $\mathrm{Zn}$ has been ascribed to a rapid generation of $\mathrm{H}_{2} \mathrm{O}_{2}$ and $\mathrm{O}_{2}{ }^{-}$in tobacco ${ }^{38}$. Indeed lipid peroxidation is one of the first consequences of oxidative stress. Intensification of lipid peroxidation due to excess $\mathrm{Zn}$ in plans has been attributed to in increasing activity of membrane-bound lipoxygenase, which leads unsaturated fatty acids oxidation, oxidative stress induction and finally MDA generation ${ }^{15,32}$. Degree of tolerance to the oxidative stress induced by metals is highly dependent on enzymatic and non-enzymatic antioxidants function, plant species and metal toxicity ${ }^{39}$. Some studies have illustrated that free proline content is enhanced under $\mathrm{Zn}$ stress conditions ${ }^{8,12,40}$. Metalinduced proline accumulation is supposed to be due to its ability to scavenge ${ }^{\circ} \mathrm{OH}$ and ${ }^{1} \mathrm{O}_{2}$, also proline is able to act as an osmolyte and metal chelator in these conditions ${ }^{16}$. In the present study, a simultaneous increase in lipid peroxidation and proline content in $C$. murale could illustrate a possible role for proline in reducing $\mathrm{Zn}$-induced oxidative stress. At higher 
concentrations, $\mathrm{Zn}$ has led to an increase in DHA contents in Brassica napus and Hydrilla verticillata ${ }^{9,15}$, suggesting that redox status of the cell changes to more oxidized forms of ascorbate. An increase in total ascorbate and DHA contents has been observed as doses of $\mathrm{Zn}$ increased in M. urundeuva ${ }^{10}$. Ascorbate, as the most abundant non-enzymatic antioxidant, exhibits a critical role in ascorbate-glutathione cycle to diminish $\mathrm{H}_{2} \mathrm{O}_{2}$ damage in chloroplasts ${ }^{41}$. In addition, ascorbate directly acts to scavenge other types of ROS ${ }^{32}$. In present study, increased ascorbate pool probably implies the active participation of this non-enzymatic antioxidant to eliminate ROS and reduce $\mathrm{Zn}$-induced oxidative stress.

Under metal stress conditions, the function of antioxidant enzymes is exerted through the elimination of ROS ${ }^{14}$. Our study clearly indicates that $\mathrm{Zn}$ induced lipid peroxidation increasing SOD, CAT and GPX activities and can confirm generation of $\mathrm{O}_{2}^{-}$and $\mathrm{H}_{2} \mathrm{O}_{2}$. Moreover, increased the activity of these enzymes may be due to the maintenance of balance in the contents of $\mathrm{O}^{-}{ }_{2}$ and $\mathrm{H}_{2} \mathrm{O}_{2}$ under $\mathrm{Zn}$ stress. Toxic $\mathrm{Zn}$ doses is known to alter differently the activity of antioxidant enzymes such as SOD, CAT and POX in Thlaspi caerulescens ${ }^{13}$, Verbascum thapsus $^{42}$, Brassica napus ${ }^{9}$, Eruca sativa ${ }^{43}$ and Triticum aestivum ${ }^{8}$. It seems that performance of antioxidant network against metal stress is particularly determined by plant species, plant organs, metal concentrations, growth conditions and exposure times. The conflicting observations in the activity of enzymatic antioxidants may be due to expression differences in genes coding these enzymes under toxic $\mathrm{Zn}$ concentrations ${ }^{44}$. $\mathrm{Zn}$, as a cofactor, is required for structural and functional stability of $\mathrm{Cu} / \mathrm{Zn}-\mathrm{SOD}$, which is the most important isoenzyme to remove $\mathrm{O}^{-}{ }_{2}$ in plant cells ${ }^{45}$, it hence has been suggested that excess $\mathrm{Zn}$ may lead to increase activity of SOD ${ }^{10}$. CAT is mainly active in peroxisomes and mitochondria, while POX acts in cytoplasm, membrane and cell wall. Both enzymes play a significant role in detoxification of $\mathrm{H}_{2} \mathrm{O}_{2}$. To detect the total POX activity, guaiacol is usually used as a non-specific electron donor to $\mathrm{H}_{2} \mathrm{O}_{2}$, in such cases; peroxidase is referred as guaiacol peroxidase ${ }^{9}$. High $\mathrm{Zn}$ concentrations were found to upregulate POX genes and increase activity of isoforms involved in wall lignifications to avoid oxidative damage ${ }^{44}$. Based on the results of this study, both CAT and GPX activity increased in response to different $\mathrm{Zn}$ levels as compared to the control. However, at the concentrations more than $150 \mu \mathrm{M} \mathrm{Zn}$, GPX activity presented a dose dependent increasing trend, whereas there was no remarkable difference in CAT activity among the plants grown in these treatments. Hence, it seems that GPX illustrates a more important role as compared to CAT to remove $\mathrm{H}_{2} \mathrm{O}_{2}$ created by toxic $\mathrm{Zn}$ levels in C. murale.

\section{CONCLUSIONS}

Taken together, based on these results, increased $\mathrm{Zn}$ concentration in the medium raised $\mathrm{Zn}$ uptake and accumulation in both shoots and roots. Nevertheless, the roots had higher capability to accumulate $\mathrm{Zn}$ compared to the aboveground parts. The $C$. murale, the population collected from industrial region surrounding steel production companies in Ahvaz, supposes to be tolerant to $\mathrm{Zn}$ concentrations up to $150 \mu \mathrm{M}$ due to maintenance of the growth and biomass. At higher $\mathrm{Zn}$ concentrations applied in the present study, the enzymatic and non-enzymatic antioxidants exhibited an important increase. However, these concentrations significantly decreased the plant growth compared to the control. This study; therefore, supports the idea that excess $\mathrm{Zn}$ doses induce oxidative stress and antioxidant defense in $C$.

murale. However, improved function of antioxidant systems along with 
increasing plant $\mathrm{Zn}$ concentration would indicate that $C$. murale, at least up to $150 \mu \mathrm{M}$, effectively increases antioxidative activities to resist against $\mathrm{Zn}$ induced toxicity. At higher concentrations, concerning significant reduction of growth, it is assumed that enhanced antioxidants system is preferentially a consequence of $\mathrm{Zn}$ stress, and hence is not probably a signal of $\mathrm{Zn}$ tolerance.

\section{ACKNOWLEDGMENTS}

This study was financed by the Research Affairs of Shahid Chamran University of Ahvaz using a MSc. thesis grant (94/3/02/31580).

\section{REFERENCES}

1. Shahzad Z, Rouached H, Rakha A. Combating mineral malnutrition through iron and zinc biofortification of cereals. Comp Rev Food Sci Food Saf. 2014; 13: 329-346.

2. Vert G, Grotz N, Dedaldechamp F, Gaymard F, Guerinot ML, Briat JF, et al. IRT1, an Arabidopsis transporter essential for iron uptake from the soil and for plant growth. Plant Cell. 2002; 14: 1223-1233.

3. Nagajyoti PC, Lee KD, Sreekanth TVM. Heavy metals, occurrence and toxicity for plants: a review. Environ Chem Lett. 2010; 8: 199-216.

4. Upadhyay RK, Panda SK. Zinc reduces copper toxicity induced oxidative stress by promoting antioxidant defense in freshly grown aquatic duckweed Spirodela polyrhiza L. J Hazard Mater. 2010; 175: 1081-1084.

5. TodeschiniV, Lingua G, D’Agostino G, Carniato F, Roccotiello E, Berta G. Effects of high zinc concentration on poplar leaves: a morphological and biochemical study. Environ Exp Bot. 2011; 71: 50-56.

6. Cambrollé J, Mancilla-Leytón JM, Muñoz-Vallés S, Luque T, Figueroa ME. Zinc tolerance and accumulation in the salt-marshshrub Halimione portulacoides. Chemosphere. 2012; 86: 867-874.

7. Ebbs SD, Kochian L. Toxicity of zinc and copper to Brassica species: implications for phytoremediation. J Environ Qual. 1997; 26: 776-781.

8. Li X, Yang Y, Jia L, Chen H, Wei X. Zinc-induced oxidative damage, antioxidant enzyme response and proline metabolism in roots and leaves of wheat plants. Ecotoxicol Environ Saf. 2013; 89: 150-157.

9. Wang C, Zhang SH, Wang PF, Hou J, Zhang WJ, Li W, et al. The effect of excess $\mathrm{Zn}$ on mineral nutrition and antioxidative response in rapeseed seedlings. Chemosphere. 2009a; 75: 1468-1476.

10. Gomes MP, Duarte DM, Carneiro MMLC, Barreto LC, Carvalho M, Soares AM, et al. Zinc tolerance modulation in Myracrodruon urundeuva plants. Plant Physiol Biochem. 2013; 67: 1-6.

11. Dhir B, Sharmila P, Saradhi PP. Hydrophytes lack potential to exhibit cadmium stress induced enhancement in lipid peroxidation and accumulation of proline. Aquat Toxicol. 2004; 66: 141-147.

12. Radić S, Babić M, Škobic D, Roje V, Pevalek-Kozlina B. Ecotoxicological effects of aluminum and zinc on growth and antioxidants in Lemna minor L. Ecotoxicol Environ Saf. 2010; 73: 336-342.

13. Wójcik M, Skórzyńska-Polit E, Tukiendorf A. Organic acids accumulation and antioxidant enzyme activities in Thlaspi caerulescens under $\mathrm{Zn}$ and $\mathrm{Cd}$ stress. Plant Growth Reg. 2006; 48: 145-155.

14. Gill SS, Tuteja N. Reactive oxygen species and antioxidant machinery in abiotic stress tolerance in crop plants. Plant Physiol Biochem. 2010; 48: 909930.

15. Wang C, Zhang SH, Wang PF, Qian J, Hou J, Zhang WJ, et al. Excess Zn alters the nutrient uptake and induces the antioxidative responses in submerged plant Hydrilla verticillata (L.f.) Royle. Chemosphere. 2009b;76: 938-945.

16. Matysik J, Alia BB, Mohanty P. Molecular mechanisms of quenching of reactive oxygen species by proline under stress in plants. Curr Sci. 2002; 82: 225-532. 
17. Siddiqi MY, Glass ADM, Ruth TJ, Rufty T. Studies of the uptake of nitrate in barley: I. Kinetics of ${ }^{13} \mathrm{NO}_{3}$ influx. Plant Physiol. 1990; 93: 1426-1432.

18. Kovacs B, Gyori Z, Prokisch J, Loch J, Daniel P. A study of plant sample preparation and Inductively Coupled Plasma Emission Spectrometry parameters. Commun Soil Sci Plan. 1996; 27: 1177-1198.

19. Rosén K, Eriksson J, Vinichuk M. Uptake and translocation of ${ }^{109} \mathrm{Cd}$ and stable Cd within tobacco plants (Nicotiana sylvestris). J Environ Radioactiv. 2012; 113: $16-20$.

20. Lichtenthaler HK. Chlorophylls and carotenoids: Pigments of photosynthetic biomembranes. Methods Enzymol. 1987; 148: 350-382.

21. Heath RL, Packer L. Photoperoxidation in isolated chloroplasts 1 . Kinetics and stoichiometry of fatty acid peroxidatoin. Arch Biochem Biophys. 1968; 125: 189-198.

22. Mukherjee SP, Choudhuri MA. Implications of water stress-induced changes in the levels of endogenous ascorbic acid and hydrogen peroxide in Vigna seedlings. Physiol Plant. 1983; 58: 166-170.

23. Bates LS, Waldren RP, Teare ID. Rapid determination of free proline for water stress studies. Plant Soil. 1973; 39: 205-207.

24. Qiu RL, Zhao X, Tang XZ, Yu FM, Hu PJ. Antioxidative response to Cd in a newly discovered cadmium hyperaccumulator, Arabis paniculata F. Chemosphere. 2008; 74: 6- 12.

25. Bradford MM. A rapid and sensitive method for quantification of microgram quantities of protein utilizing the principle of protein-dye binding. Anal Biochem. 1976; 72: 248-254.

26. Aebi H. Catalase in vitro. Methods Enzymol. 1984; 105: 121-126.

27. Hemeda HM, Klein BP. Effects of naturally occurring antioxidants on peroxidase activity of vegetable extracts. J Food Sci. 1990; 55: 184-185.

28. Beauchamp C, Fridovich I. Superoxide dismutase: improved assays and an assay applicable to acrylamide gels. Anal Biochem. 1971; 44: 276-28.

29. Pietrini F, Iori V, Bianconi D, Mughini G, Massacci A, Zacchini, M. Assessment of physiological and biochemical responses, metal tolerance and accumulation in two eucalypt hybrid clones for phytoremediation of cadmiumcontaminated waters. J Environ Manage. 2015; 162: 221-231.

30. Yang Y, Sun C, Yao Y, Zhang Y, Achal V. Growth and physiological responses of grape (Vitis vinifera "Combier") to excess zinc. Acta Physiol Plant. 2011; 33:1483-1491.

31. Caldelas C, L. Araus J, Febrero A, Bort J. Accumulation and toxic effects of chromium and zinc in Iris pseudacorus L. Acta Physiol Plant. 2012; 34:12171228.

32. Chaoui A, Mazhoudi S, Ghorbal MH, Ferjani EE. Cadmium and zinc induction of lipid peroxidase and effects on antioxidant enzyme activities in bean (Phaseolus vulgaris L.). Plant Sci. 1997; 127: 139-147.

33. Cherif J, Derbel N, Nakkach M, Bergmann H, Jemal F, Lakhdar ZB. Analysis of in vivo chlorophyll fluorescence spectra to monitor physiological state of tomato plants growing under zinc stress. J Photochem Photobiol B. 2010; 101: 332-339.

34. Vaillant N, Monnet F, Hitmi A, Sallanon H, Courdet A. Comparative study of responses in four Datura species to a zinc stress. Chemosphere. 2005; 59: 1005-1013.

35. De Magalhaes CCP, Cardoso D, Dos Santos CP, Chaloub RM. Physiological and photosynthetic responses of Synechocystis aquatilis f. aquatilis (Cyanophyceae) to elevated levels of zinc. J Phycol. 2004; 40: 496-504.

36. Bouvier F, Backhaus RA, Camara B. Induction and control of chromoplast specific carotenoid genes by oxidative stress. J Biol Chem. 1998; 273: 3065130659.

37. Boussiba S. Carotenogenesis in the green alga Haematococcus pluvialis: cellular physiology and stress response. Physiol Plant. 2000; 108: 111-117.

38. Źrobek-Sokolink A, Asard H, Górska-Koplińska K, Górecki RJ. Cadmium and zinc-mediated oxidative burst in tobacco BY-2 cell suspension cultures. Acta Physiol Plant. 2009; 31:43-49. 
39. Barrameda-Medina Y, Montesinos D, Romero L, Blasco B, Ruiz JM. Role of GSH homeostasis under $\mathrm{Zn}$ toxicity in plants with different $\mathrm{Zn}$ tolerance. Plant Sci. 2014; 227: 110-121.

40. Paradisone V, Barrameda-Medina Y, Montesinos-Pereira D, Romero L, Esposito S, Ruiz JM. Roles of some nitrogenous compounds protectors in the resistance to zinc toxicity in Lactuca sativa cv. Phillipus and Brassica oleracea cv. Bronco. Acta Physiol Plant. 2015; 37: 137

41. Chao YY, Hong CY, Kao CH. The decline in ascorbic acid content is associated with cadmium toxicity of rice seedlings. Plant Physiol Biochem. 2010; 48: 374-381.

42. Morina F, Jovanović L, Kukavica B, Veljović-Jovanović S. Peroxidase, phenolics and antioxidative capacity of common mullein (Verbascum thapsus L.) grown in zinc excess. Arch Biol Sci Belgrade. 2008; 60: 687-695.

43. Ozdener Y, Aydin BK. The effect of zinc on the growth and physiological and biochemical parameters in seedlings of Eruca sativa (L.) (Rocket). Acta Physiol Plant. 2010; 32:469-476.

44. Van de Mortel JE, Villanueva LA, Schat H, Kwekkeboom J, Coughlan S, Moerland PD, et al. Large expression differences in genes for iron and zinc homeostasis, stress response, and lignin biosynthesis distinguish roots of Arabidopsis thaliana and the related metal hyperaccumulator Thlaspi caerulescens. Plant Physiol. 2006; 142: 1127-1147.

45. Song FN, Yang CP, Liu XM, Liu GB. Effect of salt stress on activity of superoxide dismutase (SOD) in Ulmus primula L. J For Res. 2006;17: 13-16.

Received: August 14, 2016

Accepted: June 20, 2017 